\title{
First report of Wolbachia in Damaeus onustus (Acari: Oribatida)
}

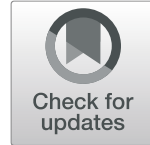

Edyta Konecka ${ }^{*}$, Ziemowit Olszanowski ${ }^{2}$ and Aleksandra Jagiełło ${ }^{1,2}$

\begin{abstract}
Purpose: Little is known about the distribution and phylogeny of bacterial endosymbionts in oribatid mites (Acari: Oribatida). Thus, we undertook the issue of occurrence of these microbial symbionts in this arthropod group.

Methods: We used PCR technique for detection of Wolbachia in Damaeus onustus. Phylogenetic analysis of the bacterium was conducted based on the 165 rDNA sequence.

Results: To the best of our knowledge, we present a novel finding of Wolbachia infection in the sexually reproducing oribatid mite, D. onustus. The presence of uninfected individuals (ca. 93\%) suggests that the bacteria do not function as primary symbionts. A comparison of the bacterial 710-bp 16S rDNA sequence detected in the oribatid mite with the sequences deposited in GenBank revealed its $92-93 \%$ similarity to the 165 rDNA sequences of Wolbachia identified in some springtails (Collembola) and Bryobia sp. mite. Bacteria from D. onustus showed phylogenetic relationships with Wolbachia from springtails, Megalothorax minimus and Neelus murinus, which were included by other authors into a separate Wolbachia clade.
\end{abstract}

Conclusion: Our finding suggests that the strains of Wolbachia from D. onustus may form a new Wolbachia supergroup.

Keywords: Wolbachia, 165 rDNA, Oribatida, Phylogenetic analysis

\section{Findings}

Wolbachia is one of the most frequent intracellular symbiont of invertebrates: arthropods and nematodes. It is estimated that $52 \%$ of arthropod species are infected with Wolbachia (Weinert et al. 2015; Huang et al. 2019). The bacterium is responsible mainly for manipulating its host reproduction (Ali et al. 2016; Mariño et al. 2017) and causing sex-ratio distortion in the infected population (Salunkhe et al. 2014; Duplouy and Hornett 2018). However, the range of its impact is much broader and includes host fitness (Zug and Hammerstein 2015; Liu et al. 2018), viral infection inhibition (Geoghegan et al. 2017; Tan et al. 2017), and defense against pathogens through the involvement in the production of host antipredator and alarm pheromones (Becerra et al. 2015).

\footnotetext{
* Correspondence: edkon@amu.edu.pl

${ }^{1}$ Department of Microbiology, Faculty of Biology, Adam Mickiewicz University in Poznań, Uniwersytetu Poznańskiego 6, 61-614 Poznań, Poland Full list of author information is available at the end of the article
}

Wolbachia is transmitted vertically through the egg cytoplasm, from mother to offspring within the host population (Zhao et al. 2013; Guo et al. 2018). Horizontal transmission of the endosymbiont between hosts can also occur (Kremer and Huigens 2011; Brown and Lloyd 2015; Ahmed et al. 2016; Pietri et al. 2016) and is usually inferred from the presence of similar or identical bacterial strains in two unrelated host species. Food may be a medium for Wolbachia transmission among similarly feeding invertebrates, and sharing the same diet may promote horizontal transmission of these bacteria (Haine et al. 2005; Sintupachee et al. 2006; Li et al. 2016; Chrostek et al. 2017). The ingestion of infected carcasses or eggs could be a possible source of Wolbachia introduction, and eating dead invertebrates with bacterial cells inside their tissues may facilitate horizontal transmission of Wolbachia (Brown and Lloyd 2015).

(c) The Author(s). 2020 Open Access This article is licensed under a Creative Commons Attribution 4.0 International License, which permits use, sharing, adaptation, distribution and reproduction in any medium or format, as long as you give appropriate credit to the original author(s) and the source, provide a link to the Creative Commons licence, and indicate if changes were made. The images or other third party material in this article are included in the article's Creative Commons licence, unless indicated otherwise in a credit line to the material. If material is not included in the article's Creative Commons licence and your intended use is not permitted by statutory regulation or exceeds the permitted use, you will need to obtain permission directly from the copyright holder. To view a copy of this licence, visit http://creativecommons.org/licenses/by/4.0/. 
Outside the host tissue, Wolbachia cannot be cultured in laboratory conditions using conventional bacteriological techniques. Identification and distribution of the endosymbiont in different hosts rely on molecular PCRbased screening methods. Sequence analysis of $16 \mathrm{~S}$ rDNA and housekeeping genes of Wolbachia provides information useful in typing, evolutionary research, and phylogeny of these bacteria (Baldo et al. 2006; Werren et al. 2008). Different sets of genes are applied in the symbiont characterization. Phylogenetic analysis is based on 16S rDNA and housekeeping genes, for example, $a t p D$ (ATP synthase beta chain), dnaA (chromosomal replication initiator protein), and topI (DNA topoisomerase I) (Crainey et al., 2010). The wsp gene coding for the Wolbachia surface protein is also a reliable tool in the bacteria phylogeny (Baldo et al. 2006). Currently, strains of genus Wolbachia are divided into supergroups A-Q (Glowska et al. 2015).

Although a few studies on endosymbionts in oribatid mites (Acari: Oribatida) have been conducted (PierrotMinnot and Norton 1997; Weeks et al. 2003; Liana and Witaliński 2010; Konecka and Olszanowski 2015, Konecka and Olszanowski 2019a, Konecka and Olszanowski 2019b, Konecka and Olszanowski 2019c, Konecka and Olszanowski 2019d, Konecka et al. 2019), still little is known about the distribution and phylogeny of microorganisms in this arthropod group. We identified Wolbachia in Damaeus onustus. Phylogenetic analysis of the bacterium was conducted based on the $16 \mathrm{~S}$ rDNA sequence.
Fifteen individuals of the oribatid mite, D. onustus (Acari: Oribatida) were isolated from a sample of soil and litter collected in a deciduous forest in the Wkrzańska Forest, West Pomeranian Voivodeship in Poland ( $\left.53^{\circ} 58^{\prime} \mathrm{N}, 14^{\circ} 43^{\prime} \mathrm{E}\right)$.

DNA was extracted using the Genomic Mini kit (A\&A Biotechnology). Amplifications of the 781-bp product of Wolbachia $16 \mathrm{~S}$ rDNA were performed in a standard PCR mixture with 553F_W (5'-CTTCATRYACTCGAGT TGCWGAGT- $\left.3^{\prime}\right)$ and 1334R_W (5'-GAKTTAAAYCGYGCAGGBGTT-3') primers, as presented by Simões et al. (2011). A negative control without DNA template was included in the reaction. The PCR program was as follows: $94{ }^{\circ} \mathrm{C}$ for $2 \mathrm{~min} ; 35$ cycles of $94{ }^{\circ} \mathrm{C}$ for $30 \mathrm{~s}, 62^{\circ} \mathrm{C}$ for $30 \mathrm{~s}$, and $72{ }^{\circ} \mathrm{C}$ for $45 \mathrm{~s}$; and $72{ }^{\circ} \mathrm{C}$ for $10 \mathrm{~min}$ (Simões et al. 2011). Amplicons were electrophoresed, sequenced with BigDye Terminator v3.1 on an ABI Prism 3130XL Analyzer (Applied Biosystems), and analyzed with BLASTn. The 710-bp 16S rDNA sequence was deposited in GenBank under accession no. MH921824.

The 16S rDNA sequence of Wolbachia from D. onustus was aligned with the loci identified in other invertebrate hosts. The alignment of 32 Wolbachia sequences was constructed with the use of CLUSTAL W (Thompson et al. 1994). An outgroup of Ehrlichia spp. sequences was added. The jModelTest 2 software (Darriba et al. 2012) was used to select the optimal model of sequence evolution. The General Time Reversible model with gamma distribution among site rate variation $(G T R+G)$ was selected. Phylogenetic analysis was conducted using MEGA

Table 1 Wolbachia strains used in phylogenetic analysis

\begin{tabular}{ll}
\hline Designation of Wolbachia supergroup & Host of Wolbachia \\
\hline A & Drosophila melanogaster, Telema cucurbitina \\
B & Drosophila simulans, Armadillidium vulgare \\
C & Dirofilaria immitis, Onchocerca ochengi \\
D & Litomosoides sigmodontis \\
E & Ceratozetes thienemanni, Mesaphorura italica, Gustavia microcephala, Folsomia candida, Megalothorax incertus \\
F & Coptotermes acinaciformis, Nasutitermes nigriceps \\
H & Zootermopsis angusticollis, Zootermopsis nevadensis \\
I & Ctenocephalides felis, Orchopeas leucopus \\
J & Dipetalonema gracile \\
K & Bryobia sp. \\
L & Radopholus similis \\
M & Brevicoryne brassicae, Aphis fabae \\
N & Toxoptera aurantii \\
O & Bemisia tabaci \\
P & Syringophilopsis turdus, Torotrogla merulae \\
Q & Torotrogla cardueli \\
? & Damaeus onustus, Megalothorax minimus, Neelus murinus \\
\hline
\end{tabular}


version 6.0 (Tamura et al. 2013). The maximum likelihood bootstrap support was determined by using 1000 bootstrap replicates. Recombination in genes between strains was detected by the $\phi$ test using the SplitsTree4 software (Huson and Bryant 2006).

To the best of our knowledge based on an extensive literature search, this is the first report of Wolbachia infection in the sexually reproducing oribatid mite $D$. onustus. We examined 15 specimens of D. onustus and only one of them was infected with Wolbachia. The low occurrence of infected individuals in this small sample (ca. 7\%) suggests that the bacteria do not function as primary symbionts.

The 710-bp 16S rDNA sequence of Wolbachia was deposited in GenBank under accession no. MH921824. The $\phi$ test did not find statistically significant evidence of recombination $(p=0.4885)$. A comparison of the bacterial 16S rDNA sequence detected in D. onustus with the sequences deposited in GenBank revealed similarity of 9293\% to the $16 \mathrm{~S}$ rDNA sequences of Wolbachia identified in springtails (Collembola): Megalothorax minimus (accession no. KC767945), M. incertus (accession no. KT799584), and Neelus murinus (accession no. KC767946). The Wolbachia sequence was also highly similar (92\%) to mite, Bryobia sp. (accession no. EU499316). These sequences were included in phylogenetic analysis of bacteria together with Wolbachia sequences representing supergroups A-Q (Table 1). Phylogeny based on the $16 \mathrm{~S}$ rDNA and $f t s Z$ gene sequences of $M$. minimus and $N$. murinus bacteria was presented by Tanganelli et al. (2014). These authors found that Wolbachia from the two species of springtails did not cluster with known Wolbachia supergroups and formed a separate

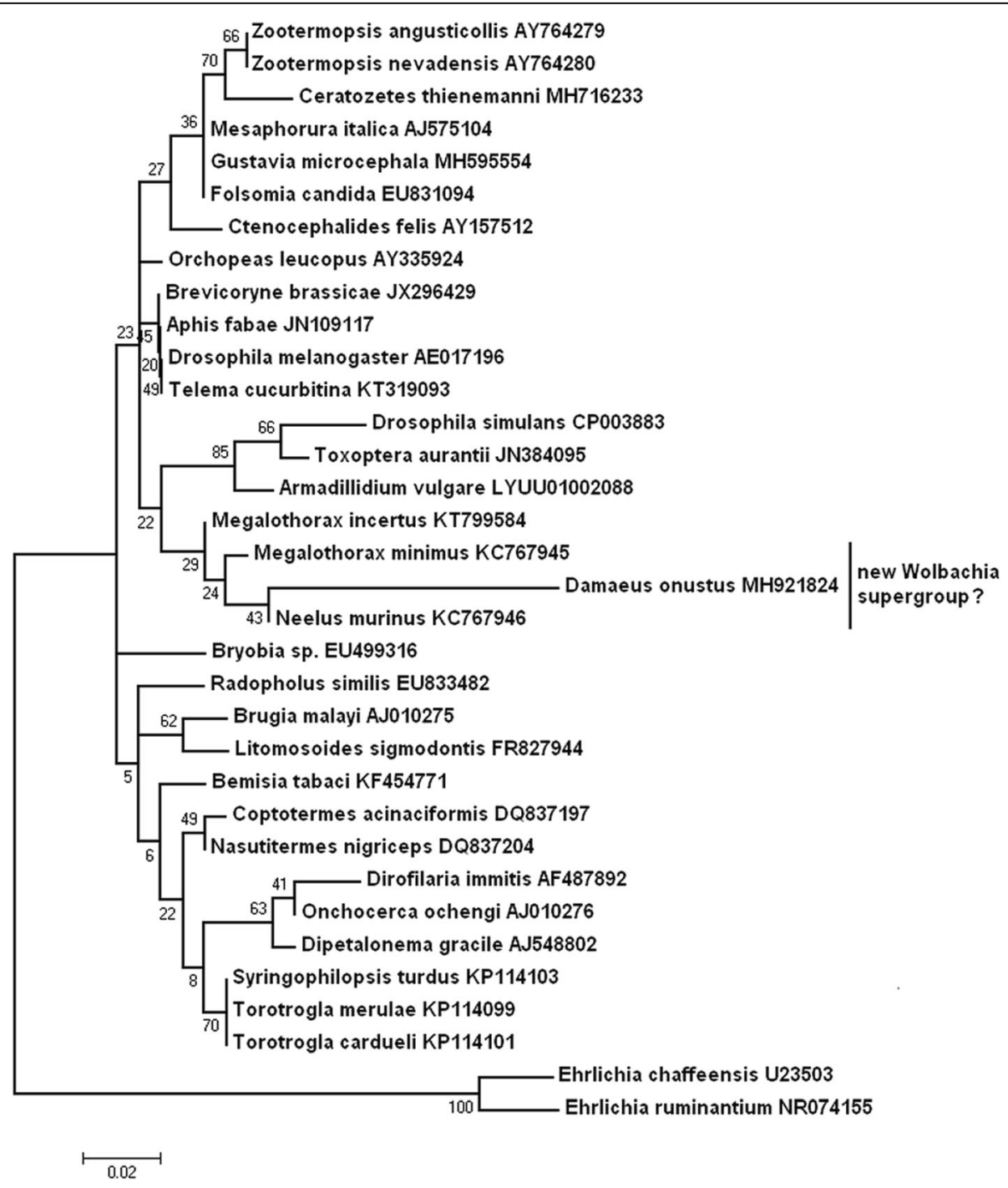

Fig. 1 Maximum likelihood reconstruction of Wolbachia phylogeny based on the sequences of 165 rDNA. Strains are designated by the names of their hosts, except for the outgroup. NCBI accession numbers for sequences are presented after the names of hosts. Bar, substitutions per nucleotide. Bootstrap values based on 1000 replicates are shown on the branches 
clade. Our research confirmed their findings. Wolbachia from the oribatid mite, $D$. onustus, showed phylogenetic relationships with Wolbachia from M. minimus and N. murinus, and these three bacterial strains clustered together (Fig. 1). Oribatida and Collembola may coexist in the same soil habitat (Kováč et al. 2001; Huhta et al. 2010), and horizontal transfer of bacteria between these two groups of invertebrates cannot be excluded, which may explain the close relationship between the bacterial strains from $D$. onustus and springtails.

Our study is consistent with the observation of Tanganelli et al. (2014) that Wolbachia strains from M. minimus and $N$. murinus are phylogenetically distinct from supergroup E bacteria from other springtails, Mesaphorura italica and Folsomia candida. Supergroup E is also represented by oribatid mites: Gustavia microcephala (Konecka et al. 2019) and Ceratozetes thienemanni (Konecka and Olszanowski 2019a). Our results suggested that Wolbachia from Oribatida formed two distantly related supergroups and confirmed the fact that the bacteria that infected Collembola also clustered into two separate supergroups. Further analysis, including bacteria phylogeny based on the sequences of housekeeping genes is required to explain the membership of Wolbachia from $D$. onustus to a potentially new Wolbachia supergroup.

In conclusion, our study presents for the first time the occurrence of Wolbachia infection in Oribatida D. onustus. The analysis of the 16S rDNA sequence of Wolbachia from the mite indicated similarity and phylogenetic relationship with bacteria found in springtails, M. minimus and $N$. murinus. Our discovery suggested that the strains may form a new Wolbachia supergroup. The role of these bacteria in D. onustus remains unknown and also needs further investigations. Nevertheless, the effect of parthenogenesis induction by Wolbachia could be excluded considering the fact that $D$. onustus is a sexually reproducing species.

\section{Competing interests}

The authors declare no conflicts of interest.

\section{Ethics approval and consent to participate}

All work performed in studies involving invertebrate animals (mites) was done in compliance of the ethical standards following for the environmental samples. This article does not contain any studies with human participants, laboratory animals, or vertebrate animals. The informed consent was not applicable.

\section{Authors' contributions}

EK and ZO designed the study and planned the experiments. AJ collected the sample. EK, ZO, and AJ carried out the experiments. EK analyzed the data and wrote the manuscript with input from $Z \mathbf{O}$. The authors read and approved the final manuscript.

\section{Author details}

${ }^{1}$ Department of Microbiology, Faculty of Biology, Adam Mickiewicz University in Poznań, Uniwersytetu Poznańskiego 6, 61-614 Poznań, Poland.

${ }^{2}$ Department of Animal Taxonomy and Ecology, Faculty of Biology, Adam

Mickiewicz University in Poznań, Uniwersytetu Poznańskiego 6, 61-614

Poznań, Poland.

Received: 16 October 2019 Accepted: 13 May 2020

Published online: 15 June 2020

\section{References}

Ahmed MZ, Breinholt JW, Kawahara AY (2016) Evidence for common horizontal transmission of Wolbachia among butterflies and moths. BMC Evol Biol 16: 118 https://doi.org/1186/s12862-016-0660-x

Ali H, Hou Y, Tang B, Shi Z, Huang B, Muhammad A, Sanda NB (2016) Way of reproductive manipulation and biology of Wolbachia pipientis. J Exp Biol Agri Sci 4(2):156-168. https://doi.org/10.18006/2016.4(2).156.168

Baldo L, Dunning Hotopp JCD, Jolley K, Bordenstein SR, Biber SA, Choudhury RR, Hayashi C, Maiden MCJ, Tettelin H, Werren JH (2006) Multilocus sequence typing system for the endosymbiont Wolbachia pipientis. Appl Environ Microbiol 72:7098-7110. https://doi.org/10.1128/AEM.00731-06

Becerra JX, Venable GX (2015) Saeidi V (2015) Wolbachia-free heteropterans do not produce defensive chemicals or alarm pheromones. J Chem Ecol 41:593601. https://doi.org/10.1007/s10886-015-0596-4

Brown AN, Lloyd VK (2015) Evidence for horizontal transfer of Wolbachia by a Drosophila mite. Exp Appl Acarol 66:301-311. https://doi.org/10.1007/s10493015-9918-z

Chrostek E, Pelz-Stelinski K, Hurst GDD, Hughes GL (2017) Horizontal transmission of intracellular insect symbionts via plants. Front Microbiol 8:2237. https://doi. org/10.3389/fmicb.2017.02237

Crainey JL, Wilson MD, Post RJ (2010) Phylogenetically distinct Wolbachia gene and pseudogene sequences obtained from the African onchocerciasis vector Simulium squamosum. Int J Parasitol 40:569-578. https://doi.org/10.1016/j. ijpara.2009.10.017

Darriba D, Taboada GL, Doallo R (2012) Posada D (2012) jModelTest 2: more models, new heuristics and parallel computing. Nat Methods 9:772. https:// doi.org/10.1038/nmeth.2109

Duplouy A, Hornett EA (2018) Uncovering the hidden players in Lepidoptera biology: the heritable microbial endosymbionts. PeerJ 6:e4629. https://doi. org/10.7287/peerj.preprints.26768v1

Geoghegan V, Stainton K, Rainey SM, Ant TH, Dowle AA, Larson T, Hester S, Charles PD, Thomas B, Sinkins SP (2017) Perturbed cholesterol and vesicular trafficking associated with dengue blocking in Wolbachia infected Aedes aegypti cells. Nat Commun 8:526. https://doi.org/10.1038/s41467-017-00610

Glowska E, Dragun-Damian A, Dabert M, Gerth M (2015) New Wolbachia supergroups detected in quill mites (Acari: Syringophilidae). Infect Genet Evol 30:140-146. https://doi.org/10.1016/j.meegid.2014.12.019

Guo Y, Hoffmann AA, Xu XQ, Mo PW, Huang HJ, Gong JT, Ju JF, Hong XY (2018) Vertical transmission of Wolbachia is associated with host vitellogenin in Laodelphax striatellus. Front Microbiol 9:2016. https://doi.org/10.3389/fmicb. 2018.02016

Haine ER, Pickup NJ, Cook JM (2005) Horizontal transmission of Wolbachia in Drosophila community. Ecol Entomol 30:464-472. https://doi.org/10.1111/j. 0307-6946.2005.00715.x

Huang HJ, Cui JR, Chen J, Bing XL, Hong XY (2019) Proteomic analysis of Laodelphax striatellus gonads reveals proteins that may manipulate host reproduction by Wolbachia. Insect Biochem Mol Biol 113:103211. https://doi. org/10.1016/j.jibmb.2019.103211

Huhta V, Siira-Pietikäinen A, Penttinen R, Räty M (2010) Soil fauna of Finland: Acarina, Collembola and Enchytraeidae. Memoranda Soc Fauna Flora Fenn 86:59-82

Huson DH, Bryant D (2006) Application of phylogenetic networks in evolutionary studies. Mol Biol Evol 23:254-267. https://doi.org/10.1093/molbev/msj030

Konecka E, Olszanowski Z (2015) A screen of maternally inherited microbial endosymbionts in oribatid mites (Acari: Oribatida). Microbiol (SGM) 161:15611571. https://doi.org/10.1099/mic.0.000114

Konecka E, Olszanowski Z (2019a) Phylogenetic analysis based on the 16S rDNA, gltA, gat $B$, and $h c p A$ gene sequences of Wolbachia from the novel host Ceratozetes thienemanni (Acari: Oribatida). Infect Gene Evol 170:175-181. https://doi.org/10.1016/j.meegid.2019.01.032 
Konecka E, Olszanowski Z (2019b) A new Cardinium group of bacteria found in Achipteria coleoptrata (Acari: Oribatida). Mol Phylogenet Evolut 131:64-71. https://doi.org/10.1016/j.ympev.2018.10.043

Konecka E, Olszanowski Z (2019c) First evidence of intracellular bacteria Cardinium in thermophilic mite Microzetorchestes emeryi (Acari: Oribatida): molecular screening of bacterial endosymbiont species 76:1038-1044 https:// doi.org/10.1007/s00284-019-01717-5

Konecka E, Olszanowski Z (2019d) Detection of a new bacterium of the family Holosporaceae (Alphaproteobacteria, Holosporales) associated with the oribatid mite Achipteria coleoptrata. Biologia - Bratislava. https://doi.org/10. 2478/s11756-019-00251-w

Konecka E, Olszanowski Z, Koczura R (2019) Wolbachia of phylogenetic supergroup E identified in oribatid mite Gustavia microcephala (Acari: Oribatida). Mol Phylogenet Evol 135:230-235. https://doi.org/10.1016/j.ympev. 2019.03.019

Kováč L, L'uptáčik P, Miklisová D, Mati R (2001) Soil Oribatida and Collembola communities across a land depression in an arable field. Eur J Soil Biol 37 285-289. https://doi.org/10.1016/j.ejsobi.2011

Kremer N, Huigens ME (2011) Vertical and horizontal transmission drive bacterial invasion. Mol Ecol 20:3496-3498. https://doi.org/10.1111/j.1365-294X.2011. 05194.x

Li SJ, Ahmed MZ, Lv N, Shi PQ, Wang XM, Huang JL, Qiu BL (2016) Plantmediated horizontal transmission of Wolbachia between whiteflies. ISME J 2016:1-10. https://doi.org/10.1038/ismej.2016.164

Liana M, Witaliński W (2010) Microorganisms in the oribatid mite Hermannia gibba (C. L. Koch, 1839) (Acari: Oribatida: Hermanniidae). Biol Lett 47:37-43. https://doi.org/10.2478/v10120-009-0018-9

Liu QQ, Zhang TS, Li ChX GJW, Hou JB, Dong H (2018) Decision-making in a bisexual line and a thelytokousWolbachia-infected line of Trichogramma dendrolimi Matsumura (Hymenoptera: Trichogrammatidae) regarding behavior toward their hosts. Pest Manag Sci 74:1720-1727. https://doi.org/10. 1002/ps.4867

Mariño YA, Rodrigues JCV, Bayman P (2017) Wolbachia affects reproduction and population dynamics of the coffee berry borer (Hypothenemus hampei): implications for biological control. Insects 8:8. https://doi.org/10.3390/ insects 8010008

Perrot-Minnot MJ, Norton RA (1997) Obligate thelytoky in oribatid mites: no evidence for Wolbachia inducement. Can Entomol 129:691-698. https://doi. org/10.4039/Ent129691-4

Pietri JE, DeBruhl H, Sullivan W (2016) The rich somatic life of Wolbachia. MicrobiolOpen 5:923-936. https://doi.org/10.1002/mbo3.390

Salunkhe RC, Narkhede KP, Shouche YS (2014) Distribution and evolutionary impact of Wolbachia on butterfly hosts. Indian J Microbiol 54(3):249-254. https://doi.org/10.1007/s12088-014-0448-x

Simões PM, Mialdea G, Reiss D, Sagot MF, Charlat S (2011) Wolbachia detection: an assessment of standard PCR protocols. Mol Ecol Resour 11:567-572. https://doi.org/10.1111/j.1755-0998.2010.02955.x

Sintupachee S, Milne JR, Poonchaisri S, Baimai V, Kittayapong P (2006) Closely related Wolbachia strains within the pumpkin arthropod community and the potential for horizontal transmission via the plant. Microb Ecol 51:294-301. https://doi.org/10.1007/s00248-006-9036-x

Tamura K, Stecher G, Peterson D, Filipski A, Kumar S (2013) MEGA6: Molecular Evolutionary Genetics Analysis Version 6.0. Mol Biol Evol 30:2725-2729. https://doi.org/10.1093/molbev/mst197

Tan CH, Wong PJ, LI MI, Yang H, Ching L, O'Neill SL (2017) wMel limits zika and chikungunya virus infection in a Singapore Wolbachia introgressed Ae. aegypti strain, wMel-Sg. PLoS Negl Trop Dis 19:1-10. https://doi.org/10.1371/ journal.pntd.0005496

Tanganelli V, Fanciulli PP, Nardi F, Frati F (2014) Molecular phylogenetic analysis of a novel strain from Neelipleona enriches Wolbachia diversity in soil biota. Pedobiologia 57:15-20. https://doi.org/10.1016/j.pedobi.2013.08.004

Thompson JD, Higgins DG, Gibson TJ (1994) CLUSTAL W: improving the sensitivity of progressive multiple sequence alignment through sequence weighting, position-specific gap penalties and weight matrix choice. Nucleic Acids Res 22:4673-4680

Weeks AR, Velten R, Stouthamer R (2003) Incidence of a new sex-ratio-distorting endosymbiotic bacterium among arthropods. Proc Biol Sci 270:1857-1865. https://doi.org/10.1098/rspb.2003.2425

Weinert LA, Araujo-Jnr EV, Ahmed MZ, Welch JJ (2015) The incidence of bacterial endosymbionts in terrestrial arthropods. Proc Roy Soc Lon 282:20150249. https://doi.org/10.1098/rspb.2015.0249
Werren JH, Baldo L, Clark ME (2008) Wolbachia: master manipulators of invertebrate biology. Nature Rev Microbiol 6:741-751. https://doi.org/10. 1038/nrmicro1969

Zhao DX, Zhang XF, Chen DS, Zhang YK, Hong XY (2013) Wolbachia-host interactions: host mating patterns affect Wolbachia density dynamics. PLoS ONE 8(6):e66373. https://doi.org/10.1371/journal.pone.0066373

Zug R, Hammerstein P (2015) Bad guys turned nice? A critical assessment of Wolbachia mutualisms in arthropod hosts. Biol Rev 90:89-111. https://doi. org/10.1111/brv.12098

\section{Publisher's note}

Springer Nature remains neutral with regard to jurisdictional claims in published maps and institutional affiliations.
Ready to submit your research? Choose BMC and benefit from:

- fast, convenient online submission

- thorough peer review by experienced researchers in your field

- rapid publication on acceptance

- support for research data, including large and complex data types

- gold Open Access which fosters wider collaboration and increased citations

- maximum visibility for your research: over $100 \mathrm{M}$ website views per year

At BMC, research is always in progress.

Learn more biomedcentral.com/submissions 